\title{
Brand Reputation in Indian Marketing Environment
}

\author{
S. Sujatha
}

\begin{abstract}
Brand reputation begins by using completely records of the term "Brand." It incorporates growing a promise, production that promise and upkeeps the scenario. Brand Reputation is not something however an act of making and maintaining the emblem. Branding makes clients committed to your business. A strong brand differentiates your products from the opposition. It gives a nice photograph of your company. Brand Reputation consists of coping with the tangible and intangible characteristics of the emblem. In the case of product brands, the tangibles encompass the product itself, charge, packaging, and so on. Although within the case of carrier manufacturers, the tangibles encompass the clients' enjoy. The intangibles include emotional effect on the product/company. Branding is assembling of numerous advertising and marketing blend medium into a whole to present you an identity. It is not whatever however shooting your patron's thoughts collectively together with your brand name. It gives a photograph of a skilled, massive and reliable enterprise. In this observe to show problems, thing and evaluation an emblem Reputation in Indian Marketing environment.
\end{abstract}

Keywords : Brand Reputation, Indian Marketing.

\section{INTRODUCTION}

"B RAND" The word brand derives from the practice of branding. Many resources have their very own description for the phrase emblem and that definition has modified over the course of time pretty dramatically, At least in the view of a few present-day professionals on brands and emblem recognition. The American Marketing Association (AMA) states that manufacturers are a call, sign, image, layout or an aggregate of them which can be imagined to pick out products or services of 1 supplier and to differentiate them from the ones of any other supplier. This definition consist of many traditional elements of brands consisting of the factors associated with visual identity and clean outside elements related to businesses and brands.

\section{REVIEW OF LITERATURE}

Divya Anandh (2018) focused on operationalizing brand equity, and profiles a standard measure of that employed slanting over FMCG items. A questionnaire based survey of customers based model of brand equity was used. Customers comprised of petty shops in select villages in Trichy District, Tamilnadu. Percentage, means and correlations were used to

Revised Manuscript Received on December 05, 2019.

* Correspondence Author

S.Sujatha*, Research Scholar, Department of Commerce, Bharathiar University, Coimbatore, Tamil Nadu, India. E-mail id: sujamahadevan2@gmail.com consolidate the data for drawing inferences. This study out comes confirm that the five scopes of brand equity are strongly relate and clearly contribute in the rural brands considered for the study. Study gives a model to brand reputation over command of brand value building. The projected brand equity map representing brand awareness, brand image, brand association, perceived quality, and brand loyalty as causal drivers might be considered as a structure for creating good brand systems.

\section{ELEMENTS FORM THE BRAND}

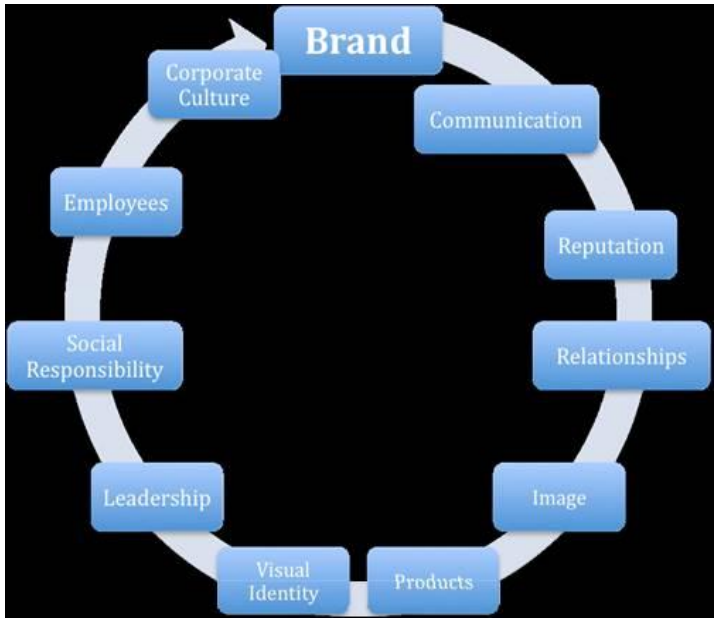

Fig 1.0 Graph supplied by myself, used Brands and Branding and Radikaali Brändi for reference material

\section{STATEMENT OF THE PROBLEM}

To talk Brand reputation on Indian advertising and marketing environment, more sizable elements have an impact on a brand than the business technique and the subsequent efforts of the organization and its buddies to bring about the logo, as referred to as within the previous phase. An emblem functions in a surroundings associated with of, on the only hand, organizational resolutions, competitive forces, marketplace systems, cultural elements, purchaser motivation, and media attention, the lenses, and filters thru which clients understand and enjoy the emblem. The brand method isn't always a given and wants to be always reviewed. Brand managers want to choose out what's the great route of movement for his or her brands particularly markets, primarily based totally on an assessment of the applicable inner and outside influences at the manufacturers.

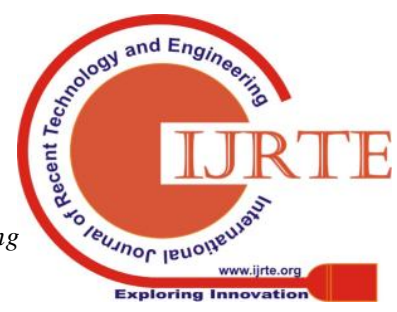




\section{Brand Reputation in Indian Marketing Environment}

Now- a- days Indian advertising environment consumer's protection rely upon their various factors observe through for your promises, Deliver authentic, patron-centric stories, behave with integrity, guard your brand, Measure emblem perception, rally your employees around your emblem, know your audience, protection, security redress, schooling, fitness, environmental to increase the elements with the purchasers. There are so many elements that influence their cognizance logo recognition on Indian advertising environment. The consciousness of brand reputation has to development ahead from their iconic role; there are each possibility that choice concerning growing relationships with their emblem reputation with their high-quality of understanding can be unique, relying at the parameters of brand popularity, the degree of danger-taking abilities. In this contemporary global, cognizance of brand reputation is a crucial role in human lifestyles. There is a threat for the knowledge of logo reputation to lose their interest and their power being affected because of the logo reputation and the large publicity. So, it's far essential to observe the trouble of the emblem reputation on Indian advertising environment. The historical past of the study is the effect of attention of logo reputation on Indian advertising and marketing environment.

\section{RESEARCH OBJECTIVES}

Based on the proposed research model, the objectives of the present study are pin down to:

1. To study on appraisal on brand reputation on Indian marketing environment

2. To examine the factor influences that brand reputation and protection in the study area.

3. To association with the demographic and socioeconomic characteristic of brand reputation on Indian marketing environment awareness and protection.

\section{PILOT STUDY}

The survey was conducted with 20 respondents to check whether the questions were related to the objectives. The researcher knows the difficulties in getting the responsive information towards brand reputation on Indian marketing environment awareness and protection factors influence of brand reputation in absolute terms and consequently the questions were adapted and thereby the respondents were asked to identify their brand reputation awareness, protection and other details. Some of the respondents opined that the questionnaire was very lengthy. Then the survey was completely changed by adding, deleting, reforming few questions and again retested and data collection was continuous after compliant to the objectivity of the result got from an adapted questionnaire.

\section{METHODOLOGY OF THE STUDY}

This study is based on brand reputation on Indian marketing environment awareness and protection and its impacts on the various factors influence of brand reputation on Indian marketing in absolute terms and consequently the questions were adapted, and thereby the respondents were asked to identify their brand reputation on Indian marketing awareness and welfare and other details both in analytical and descriptive nature. It depends upon both primary and secondary data.

\section{A. Sources of Data}

The researcher has made use of both primary and secondary sources to fulfill the objectives.

\section{B. Sampling Plan}

The population of the selected locations for the research is vast, and all the respondents could not be interviewed due to practical difficulties. Chosen only samples have been taken up for the study. Many on brand reputation on Indian marketing environment were unwilling to disclose their statement to carry out an overview especially the problem of the on brand reputation on Indian marketing. Hence the data were collected from the brand reputation organization that was willing to disclose the information. The simple random sampling method is used for the study. To have the illustration from different brand reputation psychological approach for protection is based on the hypothesis cluster sampling is done to select brand reputation on Indian marketing environment. The research was taken by simple random sampling method.

\section{Location of the Study}

The research adopted a simple random sampling method. The respondents are residents of District in the group of brand reputation on Indian marketing environment. 270 questionnaires were distributed to the consumer spread over in District. Among them, 215 surveys were collected. In which 15 polls were found incomplete and unusable. Hence, the accurate sample of the study is 200 .

\section{Statistical Tools for Analysis}

This research is based on primary data which were collected from the brand reputation on Indian marketing environment around in District through the questionnaire. Secondary data are also utilized, which were obtained from the published source like books, journals, magazines, and annual reports. The data collected from both the sources are scrutinized, edited and tabulated. The data were analyzed using statistical package for social sciences IBM- SPSS-21 have also been employed.

\section{LIMITATIONS OF THE STUDY}

The study is confined to District, and therefore the conclusion cannot be comprehensive to the entire universe. The findings, suggestions and the determination may be applicable only to the brand reputation on Indian marketing environment and not for other district. Reliability and validity of the statistical data are obtained from the opinion given by brand reputation on Indian marketing environment which may differ from time to time because of their psychological temperament. 


\section{RESULTS AND DISCUSSION}

\section{A. Discriminant Analysis}

The equation of the discriminant analysis may be written as:

$$
Z_{i j}=a+W_{1} X_{1 j}+W_{2} X_{2 j}+\ldots \ldots \ldots W_{n} X_{n j}
$$

Where $Z_{i j}$ is the Discriminant Score between the objects $i$ and $\mathrm{j}$

a- intercept

$\mathrm{W}$ is the discriminant Coefficient and $\mathrm{X}$ is the independent variable $\mathrm{i}$ for object $\mathrm{j}$

The canonical discriminant function is one which explains the relative importance of independent variables in predicting the dependent variable taken up for consideration in this study and it allowed to compare the variables. The coefficients which are having large absolute values explained the greater discriminant ability. The details of standardized canonical discriminant function are given below in Table 1.1 below:

Table 1.1: Canonical Discriminant Function coefficients in discriminant Analysis

\begin{tabular}{|c|c|c|c|c|}
\hline $\begin{array}{c}\text { Canonical } \\
\text { Correlation }\end{array}$ & $\begin{array}{c}\text { Wilks' } \\
\text { Lambda }\end{array}$ & Chi-square & Df & Sig. \\
\hline 0.133 & 0.987 & $7.902 *$ & 7 & Significant \\
\hline
\end{tabular}

Table 1.3: Table showing Canonical Correlation and Wilks' Lambda values

\begin{tabular}{|c|c|c|c|c|c|c|c|c|}
\hline \multicolumn{9}{|c|}{ Pooled Within-Groups Matrices } \\
\hline & & $\mathrm{F} 1$ & $\mathrm{~F} 2$ & $\mathrm{~F} 3$ & $\mathrm{~F} 4$ & F5 & f6 & F7 \\
\hline \multirow{7}{*}{ Correlation } & $\mathrm{F} 1$ & 1.000 & .008 & -.051 & -.039 & -.041 & -.015 & .036 \\
\hline & $\mathrm{F} 2$ & .008 & 1.000 & .039 & .047 & .024 & .101 & -.019 \\
\hline & $\mathrm{F} 3$ & -.051 & .039 & 1.000 & -.018 & .039 & .100 & .071 \\
\hline & F4 & -.039 & .047 & -.018 & 1.000 & -.012 & .014 & -.005 \\
\hline & F5 & -.041 & .024 & .039 & -.012 & 1.000 & .003 & .044 \\
\hline & f6 & -.015 & .101 & .100 & .014 & .003 & 1.000 & .037 \\
\hline & F7 & .036 & -.019 & .071 & -.005 & .044 & .037 & 1.000 \\
\hline \multicolumn{9}{|c|}{ Tests of Equality of Group Means } \\
\hline & & & $\begin{array}{c}\text { Wilks' } \\
\text { Lambda }\end{array}$ & \multicolumn{2}{|l|}{$\mathrm{F}$} & df1 & df2 & Sig. \\
\hline \multicolumn{3}{|c|}{ Brand Awareness } & .998 & \multicolumn{2}{|c|}{1.205} & 1 & 619 & .273 \\
\hline \multicolumn{3}{|c|}{ Brand Association } & 1.000 & \multicolumn{2}{|c|}{.017} & 1 & 619 & .897 \\
\hline \multicolumn{3}{|c|}{ Brand Advocacy } & .996 & \multicolumn{2}{|c|}{2.649} & 1 & 619 & .104 \\
\hline \multicolumn{3}{|c|}{ Brand Image } & 1.000 & \multicolumn{2}{|c|}{.307} & 1 & 619 & .580 \\
\hline \multicolumn{3}{|c|}{ Brand Loyalty } & 1.000 & \multicolumn{2}{|c|}{.007} & 1 & 619 & .933 \\
\hline \multicolumn{3}{|c|}{ Brand Recognition } & .994 & \multicolumn{2}{|c|}{3.655} & 1 & 619 & .056 \\
\hline \multicolumn{3}{|c|}{ Brand Reputation } & 1.000 & \multicolumn{2}{|c|}{.190} & 1 & 619 & .663 \\
\hline
\end{tabular}

From the above desk, its miles seen that Wilks'Lambda and Chi-square values are 0.987 and 7.902 which found out that there has been no substantial discrimination determined between the male and lady purchasers folks who were buying diverse merchandise through the logo influence. Moreover the $\mathrm{F}$ cost is vast at $5 \%$ level of importance, the price is more than the critical value and hence it's far considered in this take a look at and displays a correlation of 0.133 and is the reason that there may be a mild level of relationship among the grouping variable and the independent variables.

Multiple Regression Analysis among the factors of General Awareness and the Consumer Protection Awareness

To investigate the effect of things like Brand cognizance, Brand Association, Brand Advocacy, Brand image, Brand Loyalty and Brand Recognition with the logo popularity on this look at, Multiple Regression Analysis is completed through thinking about the Brand Reputation because of the structured variable and the rest of the elements as an impartial variable.

Table : 1.4: Table showing the value of Multiple Regression analysis among the factors like Brand awareness, Brand Association, Brand Advocacy, Brand image, Brand Loyalty and Brand Recognition with the brand reputation

\begin{tabular}{|c|c|c|c|c|}
\hline $\begin{array}{c}\text { Dependent } \\
\text { Variable }\end{array}$ & $\begin{array}{l}\text { Independent } \\
\text { Variable }\end{array}$ & $\begin{array}{l}\text { Regression } \\
\text { Co efficient } \\
\text { (Beta)Value }\end{array}$ & $\begin{array}{l}\text { Standard } \\
\text { Error }\end{array}$ & “t”Value \\
\hline \multirow[t]{11}{*}{$\begin{array}{c}\text { Brand } \\
\text { Reputation }\end{array}$} & (Constant) & 8.758 & 1.207 & $7.256^{* *}$ \\
\hline & $\begin{array}{c}\text { Brand } \\
\text { Awareness }\end{array}$ & .028 & 0.028 & $1.012 *$ \\
\hline & $\begin{array}{c}\text { Brand } \\
\text { Association }\end{array}$ & -.022 & 0.035 & -0.649 \\
\hline & $\begin{array}{c}\text { Brand } \\
\text { Advocacy }\end{array}$ & .047 & 0.028 & 1.680 \\
\hline & Brand Image & -.001 & 0.025 & -0.026 \\
\hline & $\begin{array}{l}\text { Brand } \\
\text { Loyalty }\end{array}$ & .027 & 0.025 & $1.072^{* *}$ \\
\hline & $\begin{array}{c}\text { Brand } \\
\text { Recognition }\end{array}$ & .030 & 0.039 & $0.776^{* *}$ \\
\hline & $\mathrm{R}$ Value & 0.325 & & \\
\hline & R2 Value & 0.246 & & \\
\hline & F Value & $4.038^{*}$ & & \\
\hline & $\begin{array}{c}\text { Total } \\
\text { Number of } \\
\text { Sample }\end{array}$ & 200 & & \\
\hline
\end{tabular}

Regarding the antecedent of brand Reputation, The F -ratio turned into 4.038 which Shows that the result of the regression model is statistically massive as the " $p$ " cost is a lot much less than the considerable degree $(\mathrm{P}=0.05)$. Also, Beta Coefficients was moreover calculated in view to recognize the significance of the variables taken into consideration in this take a look at and listed in the table above. It is also seen that the coefficient of determinant R2 cost come to be located to be 0.246 . This method that the modifications and the unit boom within the independent variable taken up in this study explain the variations of 24.6 percentages inside the logo popularity among the customers.

\section{CONCLUSION}

Hypotheses for this look at had been supported in need of the examine area emblem crucial over distant places and community brand. The parameters of this observe worried about Indian customer' affinity towards international producers and nearby variations in India. 


\section{Brand Reputation in Indian Marketing Environment}

As India turns into increasingly more economically strong, an affiliation for procurement of the arena in addition to community producers will retain boom. They have a take a look at devices priority at the form of studies already eighty done on Indian customer as it studied 3 brands. Base on the framework from preceding studies, the check analyzed the popularity of global brands and community producers amongst Indian customer. Interestingly, the take a look at discovered out that excellent part of Indian clients has a robust affinity inside the route of worldwide buying producers; but, there's a set which stays no longer decisive. India is a hastily developing financial device based completely on the energetic personal sector with emblem conscious patron. This characteristic about Indian financial tool draws international producers to set up shops inside the USA. The issues evidenced from the study of literature show display screen neighborhood constraints and authorities rules hampering the fast boom of retail in India. They have a examine may be set as a stepping stone for precise scholars to have a have a look at in depth approximately the producers in India; every international and nearby in addition to the Indian consumer alternatives. Finally, the Indian client market is ever-changing, which opens up new opportunities, and the manufacturers need to faucet into this burgeoning area.

\section{REFERENCES}

1. Brand Equity Dimensions - A study of Rural Brands Volume 119 No. 10 2018, 1347-1357 ISSN: 1311-8080

2. Irisi Kasapi (2017) Destination Branding: A Review of the City Branding Literature ISSN 2039-2117 (online) ISSN 2039-9340 (print) Mediterranean Journal of Social Sciences Vol 8 No 4July 2017

3. Dick, A. S., \& Basu, K. (1994). Customer loyalty: toward an integrated conceptual

4. Framework. Journal of the academy of marketing science, 22(2), 99-113.

5. Dillon, W., Madden, T., Kirmani, A., \& Mukherjee, S. (2001).Understanding what's in a

6. Brand rating:A model for assessing brand and attribute effects and their relationship to

7. Brand equity. Journal of Marketing Research, 38, 415-429.

8. Hoyer, W. D., \& Brown, S. P. (1990). Effects of brand awareness on choice for a

9. Common, repeated-purchase product. Journal of Consumer Research, 17, 141-148.

\section{AUTHOR PROFILE}

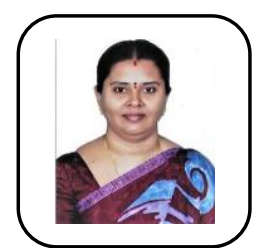

S. Sujatha, is a research scholar in Bharathiyar University Tamil Nadu, India, at present is working as Assistant Professor of Commerce in Anna Adharsh College foe Women. She is having More than 15 years of experience. She presented many papers in national and international conferences and published research articles in the leading journals. 